\title{
Discussion: Case studies of circular shaft construction in London
}

Njemile E. Faustin PhD, CEng, MICE

PhD Researcher, Department of Engineering, University of Cambridge, Cambridge, UK (corresponding author: nef22@cantab.net) (Orcid:0000-0001-5844-5633)

\section{Mohammed Z. E. B. Elshafie PhD}

Senior Lecturer in Construction Engineering, Laing O'Rourke Centre for Construction Engineering \& Technology, Department of Engineering, University of Cambridge, Cambridge, UK (Orcid:0000-0001-8307-7115)
Robert J. Mair CBE, FREng, FICE, FRS

Sir Kirby Laing Emeritus Professor of Civil Engineering, University of Cambridge, Cambridge, UK

Gerard Quigg BEng (Hons), MSC, CEng, MICE, CPEng, MIEAust Senior Tunnel Engineer, GHD, Melbourne, Australia

\section{Contribution by Gerard Quigg}

The paper under discussion (Faustin et al., 2018) is very informative and helpful to the tunnelling industry. Having worked both as a designer and a site-based engineer, the contributor has witnessed the direct effect that unvalidated assumptions can have on tunnelling projects. The value of the paper in adding to the method by New and Bowers (1994) is clear - in particular where protective strengthening measures have been adopted for utilities or buildings based on design, but deemed unnecessary following review of monitoring.

A paper by the contributor (Quigg, 2019) based on ground movement due to construction of a cable tunnel in Battersea is similar to the case studies under discussion. A $7.5 \mathrm{~m}$ internal diameter access shaft was constructed through typical London geology and ground movement was calculated using the New and Bowers (1994) formula. The shaft was constructed as a jacked caisson through the upper alluvial deposits and as a sprayed concrete lining (SCL) shaft in the clay (total depth $25 \mathrm{~m}$ ). The shaft comprised support before excavation (SBE) jacked caisson - and excavation before support (EBS) - SCL, as defined by (Faustin et. al., 2018).

The contributor concludes as follows.

Based on field observations reported by Quigg (2019), monitoring data indicated

- The maximum settlement for the jacked caisson was approximately $0.04 \% H$. Other SBE methods such as diaphragm walls, bored piles and so on provide less cause for concern and using the New and Bowers (1994) formula can be conservative;
- The maximum settlement for the SCL method was approximately $0 \cdot 06 \% H$. The New and Bowers (1994) formula provides a reasonable approach to predict ground movement for EBS shafts.

\section{Authors' reply}

The authors are grateful to Mr Quigg for his interest and comments on the paper (Faustin et al., 2018).

The New and Bowers (1994) formula provides a reasonably good estimate of ground movements due to EBS shaft construction principally in London Clay. However, it gives conservative estimates for SBE shaft construction, as shown by the field measurements presented in Figure 12 of the paper (Faustin et al., 2018). For a $7.5 \mathrm{~m}$ diameter jacked caisson and SCL shaft, the maximum ground movements would be expected to be significantly less than $0.06 \% H$, based on field observations presented in Figure 16 of the paper.

\section{REFERENCES}

Faustin NE, Elshafie MZEB and Mair RJ (2018) Case studies of circular shaft construction in London. Proceedings of the Institution of Civil Engineers - Geotechnical Engineering 171(5): 391-404. https://doi.org/10.1680/jgeen.17.00166.

New BM and Bowers KH (1994) Ground movement model validation at the Heathrow Express trial tunnel. In Proceedings of the 7th International Symposium Tunnelling '94. Chapman and Hall, London, UK, pp. 301-329.

Quigg G (2019) Battersea cable tunnel: powering regeneration in central London, UK. Proceedings of the Institution of Civil Engineers - Civil Engineering 172(2): 77-82. https://doi.org/ 10.1680/jcien.18.00020. 